Final version published at (2013) 14(4) European Business Organization Law Review, pp.471-496. The final publication is available at Springer via http://dx.doi.org/

[DOI: 10.1017/s1566752912001279].

\title{
The role of enterprise principles in shaping management duties at times of crisis
}

\section{Dr Irit Mevorach*}

\begin{abstract}
The enterprise group form presents special risks of mismanagement when entities in the group are in financial trouble. At the same time, pursing a group interest might assist in resolving the financial difficulties. In any event, delineating rules for this situation is challenging, given the variety of group structures and potential erosion of the benefit of limited liability when the regulation targets the whole group. The conflict is between "entity law" (which addresses each group entity separately) and "enterprise principles" (which address the group as a whole). There is scope for crafting the "wrongful trading" provision, now being adopted as an international standard, to accommodate the group scenario. In this context, enterprise principles should function only to help ascertain the commercial reality, rather than to override entity law.
\end{abstract}

\section{INTRODUCTION}

The paper attempts to tackle the question of managerial duties and responsibilities in the vicinity of insolvency, in a group context. Businesses today are increasingly conducted as 
corporate groups, via a network of individual subsidiaries. ${ }^{1}$ This structure represents an advanced stage of development that builds on the notions of corporate personality and limited liability. ${ }^{2}$ Thus, to the extent that the legal regime follows these principles in the context of corporate groups, each entity in a group is regarded a separate person, liable for its own debts and the directors owe their duties to the specific entity they direct. However, in the context of the group structure, stakeholders' interests may not have been confined to the entity they were dealing with, but may actually have been related to and affected by the actions of other group entities. In particular, there may be more opportunities for neglect or abuse by management of more vulnerable and dependent entities within the group, especially near insolvency. At the same time, directors of enterprise group entities may sensibly take a group-wide view when considering interests and opportunities, especially when the group is operated as an integrated business.

While the regulation of directors' duties in the vicinity of insolvency ${ }^{3}$ differs between legal systems, "wrongful trading" provisions of the type enshrined in the UK insolvency regime, ${ }^{5}$ appear to be gaining impetus, as they are now available (in different forms) in many legal systems. ${ }^{6}$ This regime imposes a duty on directors to take due account of the interests of the company's creditors when the company is in financial difficulties. Notably, the UK

\footnotetext{
*Associate Professor, University of Nottingham (LLB with distinction, LLM, Tel Aviv University; PhD, UCL). The author would like to thank Riz Mokal and an anonymous reviewer for insightful comments. The usual disclaimers apply.

${ }^{1}$ See PI Blumberg et al, Blumberg on Corporate Groups (Aspen 2005) Vol 1, s. 1.01.

${ }^{2}$ The concept of separate legal personality provides that a company is a legal person distinct from its shareholders; under a limited liability regime, the company's shareholders are not liable for its losses and debts.

${ }^{3}$ i.e. at the time when their company is facing financial difficulties or is already insolvent but not yet subject to formal insolvency proceedings.

${ }^{4}$ Some regimes are very protective of creditors and impose on the company a strict duty to initiate insolvency proceedings within a short period after the occurrence of an insolvency event (see e.g. GmbH-Gesetz, § 64(1), Aktiengesetz, §92(2)). In other regimes, directors have continuing duties to the company and this does not change as insolvency approaches (see e.g. Canadian Business Corporations Act 1985 s 241(2)(c); Peoples Department Stores Inc. $v$ Wise [2004] SCC 68 [43], though creditors may have redress via oppression remedies. See generally INSOL International, "Directors in the Twilight Zone III" (2009) 706).

5 The Insolvency Act 1986, s 214.

${ }^{6}$ E.g. in the UK, Australia, New Zealand, Singapore and South Africa. See J.L. Westbrook, C.D. Booth, C.G. Paulus, H. Rajak, A Global View of Business Insolvency Systems (The World Bank 2010), p. 54.
} 
regime now represents international best practice, as recently, the UNCITRAL insolvency Working Group ${ }^{7}$ finalised its deliberations on the topic of directors' obligations in the period approaching insolvency, and it is proposing a set of recommendations akin to the wrongful trading concept. ${ }^{8}$ The UNCITRAL Working Group acknowledged, though, that the position of directors of entities, which belong to an enterprise group, is more complex. This issue does not appear to be clearly or widely addressed within national legislation. ${ }^{9}$ The Working Group noted that it might tackle this issue in future deliberations. ${ }^{10}$

The paper asks how international standards of the kind proposed by UNCITRAL could be developed to accommodate the group problem. Specifically, the question is what role "enterprise principles" (addressing the group as a whole) should have in shaping group mismanagement regulation given their potential clash with fundamental concepts of company law, and the diversified scene of group structures. The paper considers both the responsibility of the insolvent entities' directors (who may have advanced a "group interest") and the liability of the related entities and their directors ("group liability"). Since the international standards proposed by UNCITRAL largely resemble and have been inspired by the English wrongful trading regime, the analysis draws on the English approach and experience in applying the wrongful trading provisions (and related remedies ${ }^{11}$ ) to group cases, highlighting the gaps in the legislation. Indeed, one may find it odd to focus on UK law when discussing

\footnotetext{
${ }^{7}$ Working Group V (Insolvency Law).

${ }^{8}$ See UNCITRAL Working Group V (Insolvency Law) Forty-third session, New York, 15-19 April 2013, 'Directors' obligations in the period approaching insolvency', A/CN.9/WG.V/WP.113 (hereafter: UNCITRAL WP.113) and Report of Working Group V (Insolvency Law) on the work of its forty-third session (New York, 15-19 April 2013), A/CN.9/766 (hereafter: Report of Working Group V, April 2013). The recommendations will be added to the UNCITRAL Legislative Guide on Insolvency Law (part four) (United Nations Commission on International Trade Law (UNCITRAL) (2004), UNCITRAL Legislative Guide on Insolvency Law; hereafter: UNCITRAL Insolvency Guide). The author had the privilege of participating in the deliberations as adviser to the United Kingdom delegation. All views expressed here, though, are solely those of the author.

${ }^{9}$ See UNCITRAL Working Group V (Insolvency Law) Forty-third session, New York, 15-19 April 2013, 'Enterprise groups- Directors' obligations in the period approaching insolvency', A/CN.9/WG.V/WP.115, at paras. 40 and 41.

${ }^{10}$ Report of Working Group V, April 2013, at para.105.

${ }^{11}$ E.g. English Insolvency Act 1986, s. 213; Company Directors Disqualification Act 1986.
} 
groups, as the English regime is known to be pro-entity law (strictly respecting the separate personality of group entities and the limited liability of their parent companies) as exemplified by cases such as Adams $v$ Cape $^{12}$ and by the lack of specific regulation concerning groups. ${ }^{13}$ However, legal regimes that attempted to devise a sui generis (enterprise law- based) regulation regarding liabilities and responsibilities in a group context have thus far done so with limited success. ${ }^{14}$ It is also a key argument of this paper that enterprise law should not override entity law in areas affecting the notion of limited liability. It should have a more limited role. In the context of managerial obligations, it should facilitate tackling group mismanagement by focusing on the group reality. Furthermore, to the extent that legal regimes will follow UNCITRAL's proposals to adopt a wrongful trading regime in their legal systems, the expansion of this regime to accommodate groups could have the potential to become widely applied. ${ }^{15}$

The discussion proceeds as follows. The subsequent two parts provide background analysis concerning group structures and company theory regarding limited liability in the context of groups. Thereafter, the paper considers the application of wrongful trading provisions and related remedies to the problem of insolvent entities' directors' managerial

\footnotetext{
12 [1991] 1 All ER 929.

${ }^{13}$ Generally, the group phenomenon is not systematically addressed in English company and insolvency law. An 'enterprise group' is not defined at all. Instead, the legislation provides various definitions of key players in a group (see Companies Act 2006, ss. 1159 and 1162), or concepts such as persons associated or connected with a company and shadow directors which could apply to group relationships (see Insolvency Act 1986, ss. 249, 435 and 251).

${ }^{14}$ See e.g. in Germany: Konzernrecht: para.291 et seq of the Aktiengesetz (Stock Corporation Act) 1965 which deals with governance aspects of corporate groups explicitly in legislation and has been criticised for not being sufficiently effective. It has also been observed that the German approach has developed and has become more similar to the English regime (A Daehnert "Lifting the corporate veil: English and German perspectives on group liability" [2007] International Company and Commercial Law Review 393). See also the New Zealand regime discussed below (see $\mathrm{n}$ 114-116 and accompanying texts).

${ }^{15}$ UNCITRAL standards appear in a Legislative Guide, which is not binding. In other contexts, e.g. within Europe, proposed regulation may be more prescriptive, e.g in the form of a directive. The EU Commission has recently launched a study on directors' liability including in the zone of insolvency, to support the Commission in determining its future policymaking in this area (see http://ec.europa.eu/internal_market/company/board/).
} 
obligations. The paper then examines the problem of group liability, and considers how it can be addressed within the wrongful trading regime. The final part summarises and concludes.

\section{THE DIVERSIFIED LANDSCAPE OF ENTERPRISE GROUPS AND THE COMPLEXITY OF THEIR REGULATION}

An enterprise group may be broadly defined as two or more enterprises that are interconnected by control or significant ownership. ${ }^{16}$ This would accommodate the wide variety of group structures. Indeed, entities may be linked by equity holdings or by contractual means. Furthermore, groups may be structured as hierarchical (vertical) pyramids with layers of parent and controlled companies, or they may utilise more horizontal structures, with networks of sibling group entities operating at the same level and controlled, for example, via interlocking directorates and regular meetings of the boards. ${ }^{17}$ In addition to differences in legal structure, group organisation structures may vary in terms of levels of economic integration. They may range from conglomerate and other highly diversified groups where the affiliated entities operate in different industries and have separate individual interests, ${ }^{18}$ to intermingled groups that operate de facto as one entity with commingled assets and liabilities across the entities ("asset integrated groups"). ${ }^{19}$

Between the two extremes, the integrated group, which is integrated in terms of the entities' business rather than their assets and liabilities, is a very common managerial

\footnotetext{
${ }^{16}$ This is how an enterprise group is defined in part three of the UNCITRAL Insolvency Guide (Glossary, 4(a)), which addresses the treatment of enterprise groups in insolvency and proposes to adopt doctrines such as procedural and substantive consolidation.

${ }^{17}$ Part three of the UNCITRAL Insolvency Guide, para. 6-9. See also P.T. Muchlinski, Multinational Enterprises and the Law (Oxford University Press 2007), ch. 2; I. Mevorach, Insolvency within Multinational Enterprise Groups (Oxford University Press, 2009), ch. 1.

${ }^{18}$ See R. Posner, "The Legal Rights of Creditors of Affiliated corporations: An Economic Approach" (1976) 43 U. Chi. L. Rev. 499, 510.

${ }^{19}$ Part three of the UNCITRAL Insolvency Guide, para. 10-16. See also Mevorach, Insolvency, ch. 5.
} 
structure. ${ }^{20}$ Entities in such groups operate as distinct companies, but the group as a whole collectively conducts a single business or the entities' affairs are significantly interlinked such that some entities are dependent on other entities in the group for vital functions (e.g. the provision of legal, accounting, tax, and insurance services). In these types of groups, the business interest of entities may be intertwined or entities may be managed in the pursuit of alien group objectives, which may not always squarely fit with each entity's own narrow interests. ${ }^{21}$ Here, too, there may be considerable divergence, though. Thus, integration may result from either coordination of key strategies or from close central control and involvement of a parent company in the day-to-day activities of its subsidiaries. Integration may be manifested in representations to the public and to creditors, or only revealed when considering, for example, how central functions are carried out or the way the business is financed. Integration may also be evident in the different potential legal structures - not only the classic pyramid structure where a parent controls a subsidiary, but also, for example, where the management of affiliates is coordinated across the entities' boards and the whole enterprise's "nerve centre" is in fact located outside the corporations themselves. ${ }^{22}$ Groups may also be a mix of different organisational structures, for example, a conglomerate that is split into several integrated divisions operating in different industries.

Notwithstanding the prevalence of the group phenomenon and the specific problems it presents, legal regimes often avoid providing explicit rules, which would address the particular issues arising with regard to the group structure. ${ }^{23}$ Indeed, the diversity of groups'

\footnotetext{
${ }^{20}$ See Blumberg, Corporate Groups, vol. 2, s. 6.02.

${ }^{21}$ See J.E. Antunes, Liability of Corporate Groups - Autonomy and Control in Parent-Subsidiary Relationships in U.S., EU and German Law, An International and Compative Law (Kluwer Deventer 1994), p. 116.

${ }^{22} \mathrm{Ibid}$. It has been observed that some inter-corporate alliances may lack clear legal structure. In such 'federation of companies' common directors and chief executives of the affiliates, may exercise joint influence over areas of common concern (see R.I. Tricker, Corporate Governance (Aldershot: Gower 1984), pp. 148-149; see also Muchlinski, Multinational Enterprises, pp. 67-70).

${ }^{23} \mathrm{cf}$. the German regime mentioned above (n 23) which regulates governance issues concerning groups. See also the Brazilian Act No. 6404, 1976 about stock corporations, and the Portuguese Codigo das Sociedadas Commerciais (1986), Act No. 262/86 Articles 481-508 (Title VI: Sociedades cogligadas). The English Companies
} 
legal and functional structures poses challenges for their regulation, as solutions that may be suitable for one type of group may be inappropriate for others. Generally, the classic norms of company law (corporate separate personality and limited liability) may not be well equipped to detect all the effects of groups' operations and default on their constituent entities and stakeholders. There may be, for example, specific risks deriving from the adoption of group policies, or apparent inefficiencies in the course of insolvency if group entities are handled on a separate basis. There may be confusion regarding the interests that should be considered by directors, or specific risks when intra-group transactions take place in close proximity to the onset of insolvency proceedings. Other problems arise regarding the presentation of the groups' financial affairs or in relation to certain prohibitions which could be circumvented if no consideration is given to the interrelation among entities in a group. ${ }^{24}$

The question is whether to address the group as one whole or to ignore the existence of the group (and the interrelations among the group entities) and treat each entity as a separate legal person. Here, the traditional thinking is grounded in entity law, which deems the separate entity the relevant "player", respecting its distinct corporate personality and the limited liability of its owners or affiliates. In contrast, legal analysis relying on enterprise principles is concerned with the economic reality of the over-arching business enterprise (which includes the separate but related entities that comprise it) and, where appropriate, matching rights and responsibilities to its collective economic function, i.e. to the enterprise as a whole. ${ }^{25}$ Thus, the newer enterprise conceptualisation serves to address groups as such

\footnotetext{
Act addresses some aspects pertaining to groups, e.g. financial assistance by subsidiaries for buying shares in the parent company (English Companies Act 2006, s 679).

${ }^{24}$ See T. Hadden 'Regulating Corporate Groups: An International Perspective' in J McCahery, S Picciotto and C Scott (eds.), Corporate Control and Accountability (Oxford University Press, Oxford 1993) 343, pp. 358-60.

${ }^{25}$ See A.A. Berle Jr., "The theory of enterprise entity" (1947)47 Colum. L. Rev. 343; C.M. Schmitthoff, "The Wholly Owned and the Controlled Subsidiary" (1978) J.B.L. 218; P.I. Blumberg, "The Corporate Entity in an Era of Multinational Corporations" (1990) 15 Del. J. Corp. L. 283.
} 
and, to some extent, to redefine the legal boundaries of the business organisation so that they correspond with economic reality. ${ }^{26}$

Indeed, one way of addressing the issue of group regulation would be to make a binary choice between these two approaches and apply either entity or enterprise law consistently, in relation to all legal matters arising regarding groups and with respect to all group structures. However, given the variation of group structures (especially the different levels of integration) as well as the myriad purposes of legislation and different areas of the law pertaining to groups' operation or default, a one-size-fits-all rule may not be appropriate. Both entity law and enterprise principles may have a role to play in the regulation of enterprise groups. ${ }^{27}$ Specifically, as submitted below, the choice between the two approaches should depend on the degree to which the economic benefits underlying the concept of limited liability would be defeated by adopting enterprise principles (i.e. by treating the group as a whole).

\section{THE ECONOMIC RATIONALE OF ENTITY LAW AND THE ROLE OF ENTERPRISE PRINCIPLES}

As mentioned above, entity law respects the separate personality and limited liability notions in the context of groups. The advantages of these fundamental corporate law concepts are well known. Economic analysis suggests that particularly the provision of limited liability is

\footnotetext{
${ }^{26}$ P.I. Blumberg, The Multinational Challenge to Corporation Law: the search for a new corporate personality (Oxford University Press 1993), p. 253.

${ }^{27}$ See Mevorach, Insolvency, pp. 47-48.
} 
crucial for encouraging commerce, limiting the risk of investment, and reducing various transaction costs, including those related to monitoring the company's management. ${ }^{28}$

To some extent, the advantages of limited liability are less significant in cases of centrally controlled groups with closely held subsidiaries where the parent is the sole or primary shareholder. Here the parent company is not an absentee owner investing in various companies. The parent is also likely to monitor the affairs of the subsidiary regardless. ${ }^{29}$ Yet, even these sort of groups benefit from the encapsulation of risk, which encourages commerce, since if limited liability was absent, they may not have undertaken the activities that they have organised through subsidiaries. Furthermore, the fact that entity law, particularly provisions for limited liability, facilitates the segregation of groups of assets among the different entities in a corporate group ("asset partitioning") may work to the benefit of creditors dealing with groups of different forms. Asset partitioning ensures that each entity's creditors will not need to compete with creditors of other entities in the event of insolvency and can, therefore, confine their monitoring efforts to the particular entity to which they gave credit. This, in turn, reduces the cost of credit for legal entities. ${ }^{30}$

Indeed, in certain types of groups, asset partitioning might be a deceptive exercise. This would be the case where a group was asset-integrated (i.e. the entities' assets and liabilities were intermingled), ${ }^{31}$ so that as a matter of economic reality there was no partitioning de facto. ${ }^{32}$ In such cases, enterprise law should override entity law and impose specific doctrines to allow the pooling of assets and debts in insolvency, ensuring their fair

\footnotetext{
${ }^{28}$ For the classic modern arguments see F. Easterbrook and D. Fischel, "Limited Liability and the Corporation" (1985) 52 U. Chi. L. Rev. 89; F. Easterbrook and D. Fischel, The Economic Structure of Corporate Law (Harvard University Press Cambridge MA 1991).

${ }^{29}$ See e.g. Blumberg, corporate Groups, ch. 6; K.A. Strasser, "Piercing the Veil in Corporate Groups" (2005) 37 Conn. L. Rev. pp. 637, 638-639.

${ }^{30}$ H. Hansmann and R. Kraakman, "The Essential Role of Organizational Law" (2000) 110 Yale L. J. 387.

${ }^{31}$ See text to $n 29$.

32 I called this organisational scenario a façade of asset partitioning (see Mevorach, Insolvency, pp. 224-225).
} 
and efficient distribution. ${ }^{33}$ In other circumstances, though, the group structure does not as such defeat the economic rationale of limited liability and therefore, as a matter of principle, entity law should lead, unless the particular enterprise doctrine has no effect on limited liability. ${ }^{34}$

Thus, limited liability should have full force and effect in the context of groups, subject to general exceptions imposed by the law regarding any entity, for example, via remedies in tort or wrongful trading provisions, or circumstances where the veil of incorporation may be lifted to address abuse of the corporate form and excessive risk-taking on the creditors' expense. ${ }^{35}$ However, an enterprise approach that would allow focusing on the specific group circumstances and the problems and issues that could arise in this context is still required for these general doctrines to work effectively in the group scenarios. In groups, the possibilities for cost externalisation on the expense of creditors (which is a general problem near insolvency ${ }^{36}$ ) might be broader and could arise in peculiar ways, where issues such as dominance over subsidiaries, or the use of the group connections to diminish

\footnotetext{
${ }^{33}$ Ibid., pp. 225, 255-259. UNCITRAL too suggests in recommendations regarding the treatment of enterprise groups in insolvency that substantive consolidation would be allowed when assets and debts were intermingled (UNCITRAL Insolvency Guide, part three, recommendations 219-220).

${ }^{34}$ This would be the case, for example, where regulation requires the filing of group accounts (see e.g. in Europe, the Seventh Council Directive 83/349/EEC on group accounts), or where it allows the procedural consolidation of group entities' insolvency proceedings (procedural consolidation is available in some legal systems, for example in Canada and the US, and is also recommended by UNCITRAL in the Insolvency Guide (part three on enterprise groups).

${ }^{35}$ Indeed, some creditors can protect themselves from abuse of the corporate form by contracting out limited liability (demanding personal guarantees from directors or owners) or by charging suitable interest rates or taking securities. Yet, not all creditors are in a position to calculate potential risks and respond to them effectively, especially in the vicinity of insolvency. Even sophisticated creditors may not be able to foresee all contingencies with enough clarity to contract for protection against them (see J. Landers, "Another Word on Parents, Subsidiaries and Affiliates in Bankruptcy" (1976) 43 U. Chi. L. Rev. pp. 572, 529; V. Brudney, "Corporate Bondholders and Debtor Opportunism: In Bad Times and Good" (1992) 105 Harv. L. Rev. 1821; D.D. Prentice, "Corporate Personality, Limited Liability and the Protection of Creditors" in R. Grantham and C. Rickett (eds.), Corporate Personality in the 20th Century (Hart Publishing, Oxford 1998), pp. 99, 102, 109; I.M. Ramsay, "Models of Corporate Regulation: The Mandatory/Enabling Debate" in R. Grantham and C. Rickett (eds.), Corporate Personality in the 20th Century (Hart Publishing, Oxford 1998), pp. 215, 256).

${ }^{36}$ See Prentice, Corporate Personality, p. 105; Ramsay, p. 259.
} 
the assets that might otherwise be available to creditors, might arise. ${ }^{37}$ At the same time, the group reality may reveal that a course of action taken by managers or group controllers that is apparently harmful to a subsidiary's creditors (if ignoring its connection to the group) was in fact reasonable, in a group context. Thus, an accurate analysis of the detriment and benefit to creditors may require taking account of the group economic reality. In other words, although entity law should generally prevail in matters affecting limited liability, enterprise law has a role to play too. It should not impose rights and responsibilities to the collective economic function in such cases, but it could ensure effective compliance with the general exceptions to limited liability, by highlighting the significance of the group reality.

The paper now proceeds to discuss the application of such approach to the wrongful trading regime (now becoming an international standard). It starts with the obligation of the directors of the financially troubled entities, and thereafter considers the group liability for the insolvent entity's debts. For each of these aspects, the English approach to wrongful trading and related remedies in a group context is considered, before proceeding to propose the desirable approach that could be adopted as an international standard.

\section{DIRECTORS' OBLIGATIONS WHEN THEIR ENTITY (MEMBER OF AN ENTERPRISE GROUP) IS ON THE BRINK OF INSOLVENY}

Limited liability and asset partitioning would require, in principle, that directors promote the success and pursue the interests of the specific entity they direct. They should respect the limited liability of their company and not sacrifice its interests in order to promote the interests of the group. Yet, in terms of economic reality, the interests of the group and the interests of specific entities within the group may be intertwined, especially where the group

\footnotetext{
${ }^{37}$ See J. Landers, "A Unified Approach to Parent, subsidiary and Affiliated Questions in Bankruptcy" (1975) 42 U. Chi. L. Rev. 589, p. 597.
} 
is integrated to some degree. The question is to what extent this economic reality should play a role within the law on directors' duties at the time when the company is on the brink of insolvency. ${ }^{38}$ English law is somewhat ambiguous on this issue.

\section{ENGLISH LAW'S APPROACH AND THE NEED FOR CLEARER REGULATION}

English law strictly adheres to the doctrines of corporate personality and limited liability, in the context of groups as well. ${ }^{39}$ In accordance with this approach, it requires that directors promote the success of the entity that they direct as a distinct legal person with its own separate creditors, even though it is a member of a group. ${ }^{40}$ In the context of insolvency, directors of companies that belong to an enterprise group could be exposed to liability claims brought by the insolvency representative including under the wrongful or fraudulent trading provisions, or disqualification proceedings, challenging managerial decisions, which, in the pursuit of the interest of the group, may have harmed their company. Thus, for example, in the case of Genosyis Management ${ }^{41}$ common directors of a parent and a subsidiary were found in breach of their fiduciary duties to the subsidiary. This was in circumstances where they entered into an agreement with a defaulting creditor under which the creditor paid sums to the parent company rather than to the subsidiary. The court concluded that the directors

\footnotetext{
${ }^{38}$ On the concept of pursuing the "group interest" in the ordinary course of business (subject to safeguards), see recent reform proposals in the context of the European company law harmonisation program (European Commission, Internal Markets and Services, Report of the Reflection Group on the Future of EU Company Law (5 April 2011) and Action Plan: European company law and corporate governance - a modern legal framework for more engaged shareholders and sustainable companies, COM (2012) 740/2, 12.12.2012, para. 4.6).

${ }^{39}$ See e.g. Adams v Cape Industries plc [1991] 1 All ER 929; Re Polly Peck international Plc [1996] 2 All ER 433; Ord $v$ Belhaven Pubs Ltd [1998] 2 BCLC 447.

${ }^{40}$ See Re Polly Peck International plc (No 3) [1996] 1 BCLC 428, 440.

${ }^{41}$ Re Genosyis Management Ltd, Wallach v Secretary of State for Trade and Industry [2007] 1 BCLC 208 (in the context of disqualification proceedings).
} 
had not considered the separate interests of the subsidiary and specifically the interests of the creditors (of that subsidiary) as the company was insolvent at the time of the agreement. ${ }^{42}$

English courts have acknowledged, though, that it may be difficult to draw a clear line between the interests of the subsidiary and the interests of the other entities in the group. Thus, in Facia Footwear ${ }^{43}$ the court refused an application for summary judgement against directors in circumstances where the subsidiary's directors made significant payments to other group entities under group arrangements, which included cross-guarantees. The court took into account the fact of inter-dependence between the group entities. This meant that if the corporate group collapsed, the subsidiary would collapse as well. Thus, the intention of the directors to keep the group afloat coincided with the interests of the subsidiary. ${ }^{44}$ It has been held that the question that should be asked in each case is whether the directors considered the interests of their own company in taking an action - which on its face benefited the parent company, another affiliate, or the group as a whole - or rather took the action in disregard of their own company's interest. ${ }^{45}$ Directors should be particularly careful to consider the interests of the creditors when the company is on the brink of insolvency, though English courts have admitted that it may be hard to ascertain benefits or detriments in a group context. As noted in Klempka v Miller ${ }^{46}$ :

In essence, the complaint is that the common group directors preferred the interests of International and Flexibles, to those of Films. It is a case which foreshadows for

\footnotetext{
${ }^{42}$ See also Re Mea Corporation Ltd, Secretary of State for Trade and Industry v Aviss [2007] 1 BCLC 618; Secretary of State for Business, Innovation and Skills v Doffman [2011] 2 BCLC 541.

${ }^{43}$ See Facia Footwear Ltd $v$ Hinchcliffe [1998] 1 BCLC 218.

${ }^{44}$ See also Re Oxford Pharmaceuticals Ltd, Wilson v Masters International Ltd [2010] BCC 834, where the director of a parent and subsidiary companies was not found in breach of his duties in circumstances where he made the subsidiary make certain payments to its parent company at the time leading up to the subsidiary's insolvency. It was found that the director's primary motive for making these payments was part of the process of stabilising the two companies. However, the director was found in breach of duty in relation to other payments made at a later stage when the future viability of the subsidiary was at risk.

${ }^{45}$ Charterbridge Corp Ltd v Lloyds Bank Ltd [1969] 2 All ER 1185 at 1194.

${ }^{46}$ Klempka v Miller (Re Parkside International) [2010] BCC 309 at 325.
} 
group directors an almost impossible position, when one group member becomes insolvent.

Thus, notwithstanding its strong general affirmation of the limited liability doctrine and the absence of an explicit acknowledgement of the group reality in the legislation concerning directors' duties, English law does give effect to group inter-connections in this context, though from the individual entity's point of view. However, the absence of a clear concept of group interest and a delineation of its limitations in the regulation related to insolvency can give rise to uncertainty regarding the relevant duties and to a possible mismatch with economic reality. International standards on wrongful trading of the type suggested by UNCITRAL should attempt to clarify to what extent it is legitimate for directors to consider the group interest in the vicinity of insolvency.

\section{PURSUING THE GROUP INTEREST WITHIN THE AMBIT OF ENTITY LAW: CLARIFYING BEST PRACTICE STANDARDS}

\section{Directors should mind their own entity's interests}

As suggested above, where the segregation of liabilities is at stake, entity law should generally prevail. A system that respects the interests of the creditors of each entity in a group when the company is in imminent insolvency would comply with such policy. Here, the general obligation imposed on directors under wrongful trading provisions, especially as they appear in the new international standards, ${ }^{47}$ is to have due regard to the interests of the creditors when the directors can ascertain that insolvency is imminent or unavoidable, specifically by taking reasonable steps to avoid insolvency (where possible) or minimise its

\footnotetext{
${ }^{47}$ See WP.113, recommendations 1-3.
} 
extent. In principle, in a group context, directors should ensure that they take such steps with regard to the situation and interests of the particular entity they direct.

\section{Directors may pursue a group interest as a step to avoid or minimise the effect of the} entity's insolvency

The wrongful trading provisions proposed as international standards also seek to ensure, though, that directors have sufficient flexibility to consider what is best for the company at the time of financial distress. Specifically, the standards encourage directors to explore rescue possibilities. ${ }^{48}$ In accordance with this approach, it is required that directors take steps to avoid insolvency or minimise its extent, rather than to immediately initiate insolvency proceedings. In many group scenarios, especially where groups were integrated, taking such steps effectively would require mutual assistance among and cooperation with the other entities in the group. An enterprise approach would highlight this reality.

Specifically, attention should be given to long-term or other indirect perceived benefits (from pursuing group interests or assisting other entities in the group) when considering the degree of group integration and interdependence, and the position of the entity in issue within the group enterprise. Indeed, what may be regarded as a detrimental step in circumstances where the entity has operated as a stand-alone business, not linked to other entities, may in fact be a reasonable step to take in the zone of insolvency, in a group context. For example, in circumstances where the business of the relevant subsidiary was generally dependent on the larger business of the group or on some of its related entities, that subsidiary may well need to provide funds or other benefits to its affiliated entities in an attempt to keep the group as a whole afloat including its own business. Another example is a

\footnotetext{
48 Ibid., recommendation 1, purpose of legislative provisions.
} 
situation in which a subsidiary has delayed entry into insolvency proceedings because it anticipates a deal for the sale of the group as a whole (or of a division in the group). This is more likely when a group has been integrated in terms of its business and is run as a single enterprise. In such group types, the insolvency of the entity will often affect other entities in the group (and vice versa). Yet, even in groups which were rather loosely controlled and decentralised prior to the crisis (i.e. subsidiaries were managed autonomously and only strategic key decisions were coordinated on the group level), control may tighten in the zone of insolvency, for good commercial reasons beneficial to the (now insolvent) entity's creditors. Thus, the financial crisis may accelerate and increase the centralisation of the group management, as closer coordination of the affairs may be required in order to maximise the efficient handling of the group business, for example the coordination of a reorganisation. To the extent that the interest of the insolvent entity was taken into account in the course of the "twilight zone control", and the chosen strategy was reasonable and instrumental to avoiding insolvency or minimising its effect, the directors should not be liable for wrongful trading. In fact, they may use the enterprise approach, which points out to the group reality, when defending themselves against allegations of liability for wrongful trading. Wrongful trading regimes should clarify that managing an entity in times of crisis with a group-wide perspective is legitimate, and steps to avoid or minimise the extent of insolvency may include assistance to other group entities. This would ensure due respect of limited liability and asset partitioning, while granting directors sufficient flexibility to take action that is beneficial for the financially troubled entity within the economic context of the enterprise group operation.

At the same time, in a group context, directors should be cautious not to be complacent with regard to the insolvent entity creditors' interests by, for example, providing funds or assets to other entities in the group, where this is not likely to benefit the entity, 
which is in financial trouble. As will be discussed further below, ${ }^{49}$ particular attention is required to circumstances where certain group entities were in a significant disadvantageous position within the group (for example where they were formed to "serve" the group). In those circumstances, persons other than the direct directors (e.g. the parent company) may be liable for the entity's debts, yet the entity's managers too should be able to show that they attempted to avoid harm to creditors in those scenarios, to the extent possible.

\section{Comparison with international standards regarding voidable transactions in a group} context

The approach proposed above is similar to the treatment of voidable transactions in a group context, which was previously adopted in the UNCITRAL Insolvency Guide. In that regard, UNCITRAL has suggested permitting courts to take into account that transactions took place in the context of an enterprise group. Specifically, the court should consider:

". . the relationship between the parties to the transaction; the degree of integration between enterprise group members that are parties to the transaction; the purpose of the transaction; whether the transaction contributed to the operations of the group as a whole; and whether the transaction granted advantages to enterprise group members or other related persons that would not normally be granted between unrelated parties." 50

Thus, the recommendations refer to a host of considerations of circumstances concerned with the inter-links between group entities. In other words, it is acknowledged that enterprise law has a role to play. However, the recommendations do not suggest an across-the-board

\footnotetext{
${ }^{49}$ See the discussion below regarding group obligations when entities in the group are on the brink of insolvency.

${ }^{50}$ Part three of the UNCITRAL Insolvency Guide, recommendation 217.
} 
elimination of transactions, ignoring the separation between group entities. Entity law prevails (transactions are considered to have taken place between separate entities), yet enterprise principles are utilised in order to reveal the true nature of a transaction. Thus, the general rule, according to the basic voidable transactions recommendations in the Guide, is that transactions with related persons should be more harshly scrutinised by adopting certain presumptions and facilitating proof of the elements of the provisions. ${ }^{51}$ However, the additional enterprise considerations may actually assist in upholding transactions, which might have been avoided had they taken place between unrelated parties. Indeed, a group functional structure may suggest that benefits accruing to one group entity from a transaction were highly dependent on and related to the benefits accruing to other group entities or to the group as a whole. ${ }^{52}$

Likewise, in the context of wrongful trading provisions, entity law should generally prevail in the sense that directors' obligations should be to their company. However, the group reality must be taken into account to reveal the true nature of the steps and activities taken by directors, specifically whether such steps in fact benefited the entity's creditors. Additionally, similar to the approach regarding vulnerable transactions, which more closely scrutinise transactions between related companies, special regard is required in the wrongful trading regime context to the possibility that entities were abused or neglected by the group. We now turn to discuss these scenarios, and generally what should be the obligations of persons outside the entity in distress, in relation to its insolvency.

\footnotetext{
51 UNCITRAL Insolvency Guide, recommendation 90.

${ }^{52}$ See also, I. Mevorach "Is the future bright for enterprise groups in insolvency? -analysis of UNCITRAL's new recommendations on the domestic aspects" in P Omar (ed.), International Insolvency Law: Challenges and Reforms (Ashgate, forthcoming), available at http://eprints.nottingham.ac.uk/1677/.
} 


\section{GROUP OBLIGATIONS WHEN ENTITIES IN THE GROUP ARE ON THE BRINK OF INSOLVENCY}

Limited liability's primary implication is that only the company itself is liable for its debts. In most legal systems this concept prevails both in the context of single companies and in the context of groups. ${ }^{53}$ However, as noted above, the group structure presents special opportunities for abuse of the corporate form and neglect of entities, especially in times of financial crisis. At the same time, though, coordinated management of the group could assist in saving the group business. The question is how standards regarding directors' pre insolvency obligations should accommodate this aspect of the group case - on the one hand ensuring that creditors are protected from group abuse and on the other, enabling the necessary suppleness needed for reaching effective solutions in times of financial crisis.

\section{ENGLISH LAW'S RELUCTANCE TO IMPOSE GROUP LIABILITY}

As noted above, under English law, directors owe their duties to their company. This is the case even where the company is a parent company holding subsidiaries. ${ }^{54}$ If the subsidiary becomes insolvent, the general principle is that only the subsidiary is responsible for its debts and the parent company does not bear any liability in this respect. ${ }^{55}$ Generally, ignoring limited liability ("lifting the veil") is rare and confined to circumstances in which the corporate structure was a sham and was used to evade the law. ${ }^{56}$ This narrow exception to limited liability might not cover situations where groups operated through subsidiaries for various commercial reasons, however those subsidiaries' creditors have suffered harm because of the way the group was managed, for example due to a group policy which

\footnotetext{
${ }^{53}$ See OECD, The Responsibility of Parent Company for Their Subsidiaries (1980), "Summary of comparative findings", paras. 65-70.

${ }^{54}$ Lindgreen v L. \& P Estates Ltd (1968) 1 Ch 572; Charterbridge Corp. Ltd. v. Loyds Bank [1970] 1 Ch 62.

55 See re Southard [1979] 1 WLR 1198 (CA).

${ }^{56}$ See Adams v Cape Industries plc [1991] 1 All ER 929; Trustor AB v Smallbone [2001] (No 2) [2001] 3 All ER 987; VTB Capital plc v Nutritek International Corp [2013] UKSC 5; Prest v Petrodel [2013] UKSC 34.
} 
rendered the subsidiary significantly susceptible to financial distress. ${ }^{57}$ Yet, the argument that all entities in a group of companies are to be regarded as one (the "single economic unit" argument) has been robustly rejected as a basis for lifting the corporate veil. ${ }^{58}$

Alternatively, the veil may be lifted under the wrongful (or fraudulent) trading provisions that permit imposing liability for managing the business fraudulently, or for not taking steps to minimise losses to creditors when it could be ascertained that insolvent liquidation was unavoidable. ${ }^{59}$ These provisions apply primarily to directors. However, the English fraudulent trading provision extends to any persons who were knowingly involved in carrying out the business with the intent to defraud creditors or for any other fraudulent purpose. ${ }^{60}$ The wrongful trading provision applies to directors, though it defines "director" broadly to include de facto and "shadow directors". The latter concept refers to persons in accordance with whose directions or instructions the directors of the company are accustomed to act, ${ }^{61}$ and may therefore include parent companies or their directors. ${ }^{62}$ Thus, potentially, the provisions may cover other persons outside the entity. Yet, beyond this, there is no guidance on the way the provisions should be applied in a group context. As such, English courts have been quite reluctant to impose group liability.

Generally, the application of the wrongful and fraudulent trading provisions to parent companies appears to have had little effect on the law. ${ }^{63}$ Indeed, the interpretation of the

\footnotetext{
${ }^{57}$ See text to $\mathrm{n} 78$.

${ }^{58}$ See Woolfson v Strathclyde Regional Council [1978] SC 90 (HL); cf. DHN Food Distributors Ltd v Tower Hamlets LBC [1976] 1 WLR 852 (CA).

59 Insolvency Act 1986, ss. 213-214.

60 Insolvency Act 1986, s. 213.

61 Insolvency Act 1986, s. 251.

62 See Re Hydrodan (Corby) Ltd [1994] B.C.C. 161. However, directors of corporate directors are not, without more, shadow or de facto directors (re Paycheck Services 3 Ltd [2010] UKSC 51). See also S. Wilkinson, "Piercing the Corporate Veil and the Insolvency Act 1986" (1987) 8 Co. Law. 124, 125.

${ }^{63}$ This might also be due to the reluctance of liquidators to use the funds of insolvent subsidiaries in bringing claims against shadow directors, especially as the likelihood of success may be unclear (see P.J. Omar, "The European Initiative on Wrongful Trading" (2003) 6 Insolv. Law. 239, 245). However, see the results of a survey of English cases applying the wrongful trading provision (R.J. Mokal, Corporate Insolvency Law: Theory and
} 
provisions has been rather narrow in this context - to the extent that the group reality is sometimes ignored. Thus, a finding of fraudulent trading by a parent company may require that the liquidator first establish that the subsidiary's business was carried out - by its own management - in a fraudulent manner. ${ }^{64}$ It also appears that parent companies may operate the business as one whole, give assurances to creditors of subsidiaries to persuade them to trade with a financially unstable subsidiary, and then cease providing support. This may not result in imposing liability on the parent company. ${ }^{65}$ Otherwise, to establish wrongful trading as shadow directors, a liquidator may need to show pervasive intrusion in the management of the subsidiary and the usurpation of the individual judgement of the subsidiary's directors. ${ }^{66}$ Courts are also reluctant to impose liability in circumstances where companies where grossly undercapitalised. ${ }^{67}$ Overall, English courts seem very cautious about interfering with the concepts of corporate personality and limited liability. ${ }^{68}$ It was noted, that any change in the approach might require wider investigation and possibly legislative intervention:

The circumstances in which parent companies should be liable for the debts of their subsidiaries is a matter of considerable public importance and debate. It may be that the law on this subject is inadequate. To form a view would require a much wider

Application (Oxford University Press, Oxford 2005, pp. 284-92). The survey showed that in most cases the issue of managers risk shifting in close proximity to insolvency arises in the context of either closely held firms or with regard to shadow directors. The sample of cases was small, however it consisted of all cases for which judgments or transcripts were available in electronic form. See also UNCITRAL's proposals for resolving problems of funding claims against directors (WP.113, paras. 56-57 and recommendations 10 and 11).

${ }^{64}$ Re Augustus Barnett \& Son Ltd (1986) 2 BCC 98904.

65 lbid.

${ }^{66}$ Re Hydrodan (Corby) Ltd [1994] BCC 161. Though in the context of disqualification proceedings against individual directors, the court had put emphasise on whether instructions were followed rather than whether the board's discretion was surrendered to the shadow director (Secretary of State for Trade and Industry $v$ Deverell [200] 2 BCLC 133). See also D. Milman, “A fresh light on shadow directors?" (2000) Insolv. L. 171; J. Payne, "Casting light into the shadows: Secretary of State for Trade and Industry v. Deverell" (2001) Comp. Law. 90.

67 See Re Purpoint Ltd. [1991] BCC 121.

${ }^{68} \mathrm{Cf}$. in a context of tortuous liability the case of Chandler v Cape plc ([2012] EWCA Civ 525. 
investigation of the issues of public policy than is open to a judge hearing an interlocutory application to strike out a pleading. ${ }^{69}$

Office holders will be reluctant, therefore, to initiate proceedings against affiliated entities or their directors under the English regime. Indeed, it has been observed that utilising the shadow directorship concept, in order to prove a claim for wrongful trading is a speculative venture for liquidators. ${ }^{70}$ The absence of a clear approach regarding group responsibilities renders the task of bringing group entities to account even more daring. The result is that instead of deterring group mismanagement, the current approach might deter office holders from pursuing culpable managers.

\section{ACCOMODATING THE REALITY OF GROUP MANAGEMENT AND CIRCUMSTANCES OF GROUP MISMANAGEMENT WITHIN THE BEST PRACTICE STANDARDS}

\section{Concepts such as shadow directorship provide partial solutions}

The new international standards on managerial obligations (proposed by UNCITRAL) similarly adopt an expansive view of the persons responsible for the management of a company and include persons exercising factual control and performing the functions of directors, ${ }^{71}$ also referring to the concepts of the shadow director. ${ }^{72}$ Therefore, the provisions could potentially apply to persons outside the entity. Indeed, in cases of groups, it is quite conceivable that a related entity, usually the parent, would act as a shadow director of its subsidiaries whereby, even if it would not perform the function of a director it would lurk in

\footnotetext{
${ }^{69}$ Re Augustus Barnett \& Son Ltd (1986) 2 BCC 98904, at [98908].

70 D. Milman, “A fresh light on shadow directors?” (2000) Insolv. L. 171, p. 172.

${ }^{71}$ See WP.113, recommendation 4.

72 Ibid, para. 26.
} 
the shadows and in effect centrally control the subsidiaries, which form part of an integrated closely linked enterprise. In this respect, the concept of the shadow director is particularly useful as it is based on economic reality of actual intervention in the management rather than on formal relationship of ownership of the subsidiary. ${ }^{73}$

However, the concept of shadow director may only address certain specific scenarios whereby the company's directors were accustomed to act according to the instructions of other persons. ${ }^{74}$ In a group case, questions of mutual liability may arise in other situations. This is because the commercial reality of the group is different from that of the single entity, which is managed either by its own appointed or de facto directors or by other persons that instructed the managers. An entity belonging to an enterprise group may have taken part in the overall management of the group enterprise and the group strategy may have had implications on the entity's financial situations in different ways. Thus, while a broad definition of "director", specifically the concept of the shadow director, could be helpful for group cases (as well as in cases of single companies), the principles regarding group liabilities for mismanagement in the vicinity of insolvency require some further evolution to fit with the complexity of this business structure.

\section{No strict group liability}

As proposed above, limiting the liability and responsibility of parent companies and other entities or persons within the group (to the debts of the insolvent entity) is supported by a viable economic rationale. Unless the affairs of the group entities were intermingled, the veil should not (without more) be lifted. Enterprise law should not create new duties and remedies

\footnotetext{
${ }^{73}$ See also H. Collins, "Ascription of Legal Responsibility to Groups in Complex Patterns of Economic Integration" (1990) MLR 731, p. 741.

${ }^{74}$ See ibid, p. 742 (Collins observes that the main weakness of the shadow directorship concept lies in its insistence upon a pattern of domination).
} 
in this context and a cautious approach is required. A mere parent-subsidiary relationship or the management of an enterprise as a single business is insufficient to justify mixing assets and liabilities across the entities. It is also commendable that parent companies are not generally obliged to support their subsidiaries in the event of their insolvency. Certainly, the individual shareholders or directors of the parent company should not be liable for the debts of the subsidiary merely because the parent may be liable. This would entail lifting the veil twice and would undermine the primary and fundamental aim of limited liability as a measure for promoting entrepreneurship and risk taking by individuals.

However, other affiliated entities in the group should be liable for the debts of the insolvent entity if group management was undermining the ability of that entity to avoid insolvency or to minimise its effect at the time leading up to insolvency. This is where enterprise law would come into play. Its role should once again be modest. It should not replace entity law by imposing liability based on the fact of the group (i.e. a strict liability on affiliated entities or their directors to the debts of the insolvent entity). Rather, it should assist in identifying the essence of the commercial reality in order to uphold the goals of managerial behaviour regulation in the context of insolvency. Specifically, enterprise law could be instrumental in revealing the persons that could have influenced the way the entity was managed in the vicinity of insolvency. Additionally, it can point to circumstances of abuse and mismanagement in a group context, beyond the conventional understanding of "wrongful trading". This is because enterprise law would give specific regard to group interrelationship, looking beyond the separate entity, as explained below.

\section{Enterprise law pointing to the reality of group management}


Identifying the actual responsible parties in management (that have caused harm to creditors) may be a more complex task in a group context (compared with a single company scenario) where there may be various layers of management affecting the affairs of an entity and the way it was trading leading up to the time of insolvency. In a group, parental or other related company influence over subsidiaries may not necessarily replace the decision-making process in the relevant entity as is often required for proving factual or shadow directorship. Yet, other entities in the group may still exert such influence or meddle in the subsidiary's affairs, effectively impacting its on-going business during the time of impending insolvency. This may result in undermining the ability of the subsidiary to avoid insolvency or minimise its extent. For example, a parent company may appear to provide strong support for a subsidiary (either itself or through another entity in the enterprise) during the time leading up to insolvency. Subsequently, those group entities may abandon the subsidiary when they realise it has no prospects of recovering. The subsidiary's directors may genuinely rely on the support of the related entity in continuing to trade almost as if business is as usual, yet the result could be deepening the insolvency of the subsidiary. This course of action may involve misrepresentations to voluntary creditors, which, in turn, may give rise to remedies available outside of insolvency against relevant persons. ${ }^{75}$ Yet, group support and subsequent neglect may amount to wrongful trading as well, when by imposing the group policy the interests of the insolvent subsidiary's creditors were disregarded. This is the case even if the subsidiary's directors did not surrender control and did not follow any instructions or advice. ${ }^{76}$ In this respect, specific regard should be given to groups that are integrated and the management pattern of which allows the subsidiary some degree of managerial autonomy while remaining financially dependent and significantly reliant on the strength of the enterprise. Similarly, in

\footnotetext{
${ }^{75}$ See e.g. in the UK, the remedies for misrepresentations and deceit which are directly enforceable by creditors outside insolvency (as confirmed in Contex Drouzhba $v$ Wiseman [2007] EWCA Civ 1201).

${ }^{76}$ Cf. Re Hydrodan (Corby) Ltd [1994] BCC 161 and Secretary of State for Trade and Industry v Deverell [200] 2 BCLC 133. See also Prentice, Corporate Personality, pp. 116-17.
} 
circumstances of fraud, such subsidiaries may not themselves carry out their business fraudulently, as their directors may have been unaware of the fraudulent intentions of the related company (or its directors), for instance by allowing the subsidiary to trade, knowing that it will not be able to repay its debts. The related company's potential liability should be considered, however, even when the subsidiary's own management did not carry on the business in a fraudulent manner. ${ }^{77}$

Decentralised and horizontal managerial group structures should also be taken into account. Here, it may be difficult to identify a single entity which owned and centrally controlled (or instructed) the entity in insolvency. In fact, the managements of a federation of affiliates may have acted in concert. While the entities in such groups may have their own decision-making processes and remain formally independent, a large degree of cooperation among the different boards may still exist. Thus, the directors of the insolvent entity may be well aware of the group interest and the circumstances pertaining to the decision to take a particular course of action regarding the entity. Again, they need not surrender control or avoid making judgements, but rather, in this scenario, be part of a coordinated management of the group. In these cases, if the management was reckless or fraudulent, the direct managers of the entity may be responsible, but other entities and directors outside the entity may be liable too, even though they have not overridden the judgement of the appointed directors or assumed the role of directors of the specific entity.

Thus, detrimental influence by affiliated entities or their directors, which might adversely affect creditors of insolvent entities in the group, may not be pervasive, but rather the result of collective decision-making or the consequence of group support and subsequent neglect of a subsidiary. It need not be necessarily sustained and persistent either. Decisions which affect the running of the insolvent entity may take place shortly before the

\footnotetext{
${ }^{77}$ Cf. Re Augustus Barnett \& Son Ltd (1986) 2 BCC 98904.
} 
commencement of insolvency proceedings, i.e. only at the time when insolvency has become a real threat, when there may be greater incentives to divert assets from one of the group's entities to another or abandon certain entities considered to be "lost causes". It should be acknowledged, that the fact that affiliates are economically and managerially inter-linked or are held by a parent company having the capacity to control their affairs might lead to greater intervention in times of crisis that could harm creditors.

Best practice standards regarding directors' obligations could be developed accordingly. They should impose obligations to avoid insolvency or minimise its effect not only on directors (broadly defined) but also, explicitly, on affiliated entities and their directors that could influence the insolvent entity's affairs to the detriment of its creditors, without necessarily instructing its managers in a pervasive and consistent manner. Merely relying on concepts such as de facto and shadow directors is insufficient. An enterprise approach, which focuses on the economic reality of the group's organisational and managerial structure, is required in order to facilitate the identification of those in the group that might have acted wrongly in the vicinity of a group entity's insolvency.

\section{Enterprise law pointing to particular circumstances of mismanagement and abuse}

An enterprise approach could further assist the regulation of group managerial obligations (when insolvency is looming) and facilitate tackling what may be called "group wrongful trading" by identifying particular risks of abuse and mismanagement in a group context. In this respect too, concepts such as shadow directorship are only of limited use, since they say nothing about the content of the obligation that may be imposed on related entities in a group. Indeed, group mismanagement may go beyond the conventional understanding of what 
amounts to wrongful trading and the regulation of such behaviour may require a stricter approach in certain circumstances.

Thus, in addition to the usual wrongful trading scenario, where directors (including shadow directors) continue to trade or take business risks knowing that insolvency is unavoidable and not taking sufficient steps to minimise the harm to creditors, an enterprise approach could point to specific scenarios where group entities were particularly vulnerable. Such scenarios should raise a presumption of group wrongful trading, which enterprise groups, operating in this way, could rebut only if they are able to show that they actively addressed the situation.

Managerial patterns rendering certain entities particularly vulnerable would include integrated groups, which adopted a group strategy that favoured the interests of the group as a whole (or certain parts of the group) over the interests of certain group entities. ${ }^{78}$ This could manifest itself not only in pyramid centrally controlled structures but also in horizontal patterns of groups where management of the entities was coordinated and affiliates operated in pursuit of alien group interests. Specifically alarming would be the case of the "subservient" subsidiary, ${ }^{79}$ which merely served the group, i.e. supported certain entities in the group or otherwise assisted in achieving group profit-maximisation policy, but was unable to make profits essential to meet its liabilities. Also problematic is the case of the undercapitalised subsidiary. Indeed, undercapitalisation is a probable scenario in a group context, where funds may be available from other entities in the group in the ordinary course of business- reducing the practical importance of adequate capitalisation. ${ }^{80}$.

\footnotetext{
${ }^{78}$ See Hadden, Regulating Corporate Groups, pp. 362-3.

${ }^{79}$ See A. Muscat, The liability of the holding company for the debts of its insolvent subsidiaries (Dartmouth Publishing Group, Aldershot 1996), pp. 200-201.

${ }^{80}$ See Landers, A Unified Approach, pp. 589, 597.
} 
The problem may also arise in groups with lesser degrees of integration where in the normal course of business the insolvent entity may have been independent (with minimal supervision by the parent). However, such managerial style and structure may change when financial crisis is looming. In such cases, group-wide decisions may take place to the detriment of the financially distressed entity - business opportunities may be diverted to other parts of the enterprise and/or assets may be transferred to other entities in the group at nonmarket rates. ${ }^{81}$ Subsidiaries may also be in a particularly vulnerable position if they were set up or utilised by the group to absorb losses, bad assets or the more risky activities of the business. $^{82}$

International best practice standards on directors' obligations should require, that in cases of groups that adopted a strategy which rendered certain entities vulnerable and susceptible to insolvency, those with influential control over such entities must take active steps to ensure that the entity can nonetheless avoid insolvency or (where insolvency is unavoidable due to other reasons) minimise its extent. This may include injection of funds and creation of business opportunities. Unless it is possible to show that such specific steps were taken, liability will be imposed. The office holder would only need to establish the fact that the entity in issue was in a vulnerable position within the group.

Indeed, it should also be acknowledged that it is often the group that can actually assist (rather than harm) the insolvent entity in resolving its financial difficulties, for example by providing business opportunities, new financing, guarantees to lenders and so forth. It is paramount that the law on directors' duties (extended to impose group liability in certain circumstances) does not discourage groups from taking such actions. Yet, the wrongful

\footnotetext{
${ }^{81}$ It may be possible to avoid such transactions by invoking voidable transactions provisions. However, this would depend on meeting the specific pre-requisites of the relevant provisions, notably certain strict timeframes.

${ }^{82}$ See Hadden, Regulating Corporate Groups, p. 364; C.M. Schmitthoff, 'The Wholly Owned and the Controlled Subsidiary' [1978] JBL 218, 222; Collins, Ascription, pp. 736-8.
} 
trading approach as manifested in the international standards, with the elaboration regarding groups proposed here, would in fact support and incentivise such behaviour. It would require taking steps to avoid insolvency or minimise its extent, rather than impose strict liability on related entities, while taking due account of the group reality. This means that in the absence of abusive relationship or involvement in the entity's management, related entities and their directors need not be concerned at all with taking steps to address the financial situation of the troubled entity. ${ }^{83}$ Additionally, where there was such involvement, steps taken by the group management (including in pursuing of group interests) aimed at assisting and rescuing a subsidiary would be taken into account favourably when considering potential liabilities.

\section{ALTERNATIVE MEANS FOR ADDRESSING GROUP MISMANAGEMENT}

There may be alternative ways for addressing the problem of group liability, other than by developing the wrongful trading regime. ${ }^{84}$ However, such measures are often either too wide or too narrow to address the complexity of the group scenario. One notable measure is the contribution orders regime, available in New Zealand. ${ }^{85}$ This regime appears particularly attractive since it provides a measure "tailored-made" for groups in insolvency. It is not attached to a general duty imposed on companies and directors, but rather it applies only to enterprise groups. In this respect, it allows obligating a related company to contribute funds to the insolvency estate of the company in liquidation. The contribution order is grounded on general fairness considerations, as the court may impose liability if it is "just and equitable"

\footnotetext{
${ }^{83} \mathrm{Cf}$. The Australian provisions (Australian Corporation Law 2001, s 588V) which impose a general positive duty on parent companies to safeguards the interests of insolvent subsidiaries' creditors.

84 Indeed, the UNCITRAL Insolvency Guide in the part three on the treatment of enterprise groups mention such variety of legal means to address issues of group liability, yet without making any specific recommendations (see UNCITRAL Insolvency Guide, part three, paras. 95-104).

85 New Zealand Companies Act 1993, ss. 271-272.
} 
in the circumstances. ${ }^{86}$ The court should take into account certain factors before making an order, including the extent to which the related company took part in the management of the company being wound up, its conduct towards the creditors, and the extent to which the winding up is attributable to the actions of the related company. The court is also authorised to consider such other matters as it finds fit. ${ }^{87}$

Indeed, commentators have referred to this legislation as "revolutionary" in terms of its use of enterprise principles, but further observed that it has not been significantly utilised in practice. ${ }^{88}$ A key difficulty has been determining how to reconcile the different interests of the creditors of the insolvent subsidiary and the creditors of the related company, especially where a contribution order would threaten the solvency of the group entity not already subject to insolvency proceedings. ${ }^{89}$ Indeed, the problem with the contribution order is that it is rather broad and appears to be based on enterprise law and not to arise from a separate defined duty. As such, one might argue that, while it is not fair that creditors of an insolvent subsidiary will recover their debts from a weaker entity, the creditors of the related entity may equally argue that they relied on the separate entity and did not expect to compete with the creditors of any other entities in the group. As suggested above, in areas affecting segregation of liabilities and so long as the segregation was kept and the group was not intermingled, enterprise law should assist in clarifying the economic reality, but it should not provide the basis for disregarding the corporate form. Other types of measures that impose liability based on

\footnotetext{
${ }^{86}$ See R.P. Austin, "Corporate Groups" in R. Grantham and C. Rickett (eds.), Corporate Personality in the $20^{\text {th }}$ Century (Hart Publishing, Oxford 1998), pp. 71, 84-85; Blumberg, Corporate Groups, Vol 2, s. 90.05[B].

87 The Cork Committee in the UK has referred to this regime as providing a possible solution to the problems of abuse within corporate groups. In this respect, the Cork Report observed that even with the introduction of the wrongful trading concept, English law would remain in an unsatisfactory state in terms of dealing with the potential for the abuse of the corporate group (The Insolvency Law and Practice: Report of the Review Committee (Cmnd 8558) (London: HMSO, 1982), Ch 51). The Committee eventually refrained from reaching conclusions due to the possible implication for company law, though it expressed the need for a reform to be considered.

${ }^{88}$ Blumberg, Corporate Groups, vol. 2, s. 90.02.

89 Para. 103 of the UNCITRAL Insolvency Guide, part three.
} 
structural supremacy, ${ }^{90}$ or which disregard corporate separateness based on general fairness considerations, ${ }^{91}$ are similarly inadequate unless they are tied to a finding of fraud or wrongful trading. ${ }^{92}$

Indeed, the wrongful trading regime provides adequate justification for tackling mismanagement. It is also becoming universally accepted that managers should be subject to certain specific (balanced and flexible) obligations during the time when insolvency becomes imminent or unavoidable. In a group, the managerial obligations should derive from the same principles, while enterprise law should assist in accommodating the group economic reality and facilitate tackling group mismanagement. To the extent that liability of a related entity is established on this basis, the fact that an order might then undermine the insolvency of that related entity should not affect the fact of liability and may be treated in the same way as any other claim regarding the assets of the company. Of course, there will be fewer incentives to pursue an insolvent entity. The financial state of the person who breached the obligations is also a factor to take into account when considering whether to impose the remedy and the extent of contribution. The remedies for breach of the duty may also vary and may include both contributions to the insolvency estate and the subordination of directors' claims as creditors. ${ }^{93}$ The remedy is discretionary, but the obligation should be fixed, and should derive from a finding of harm to creditors because of wrongful trading. The use of enterprise principles to accommodate the group reality within the wrongful trading regime also ensures that the range of abusive scenarios in a group context is covered. Alternative narrow concepts

\footnotetext{
${ }^{90}$ See the German regime mentioned above (n 23). The alternative regime under the German approach allows groups to formalise their enterprise relationship. In return for the power of control, the parent owes duties of compensation to the creditors and minority shareholders of the subsidiary. Yet, elective regimes as means for addressing the group problem (also once proposed on EC level in the draft $9^{\text {th }}$ Directive, and in reform proposals in the UK, both initiatives eventually abandoned) entails various practical difficulties including the lack of incentives for groups to opt for this option.

${ }^{91}$ e.g. equitable subordination (see in the US, 11 USC s. 510(c)).

92 Indeed, US courts applying the doctrine of equitable subordination would usually look for circumstances of misconduct, mismanagement fraud or undercapitalisation (see Landers, a Unified Approach, pp. 597-606).

${ }^{93}$ See under the English wrongful trading regime, the English Insolvency Act 1986, s.215(4).
} 
such as lifting the corporate veil in circumstances of sham entities, as means for addressing the problem of group liability for subsidiaries' debts, would not suffice.

\section{CONCLUDING REMARKS}

The wrongful trading regime, which has been accepted as international best practice, could be developed to accommodate the group case. The requirement that directors take steps to minimise or avoid insolvency could include activities in pursuance of a group interest where this was a reasonable step in view of the reality of the group. This way, entity law is respected while effect is given to group circumstances. Furthermore, the obligation to attempt to avoid insolvency or minimise its extent, which is imposed on managers (including de facto and shadow directors), should be elaborated to refer to group entities and their directors who had the capacity to influence the entity's affairs in a way detrimental to its creditors. Such influence might not necessarily involve instructing the subsidiary's managers in a pervasive and consistent manner. The standards should also take account of specific circumstances of group abusive relationship, which should raise a presumption of group wrongful trading.

Thus, the role designated to enterprise law here is rather modest. Enterprise law does not transcend entity law to impose specific enterprise law remedies. Indeed, this would undermine the objectives of limited liability. The approach should be a cautious one, which respects the corporate form. Yet, the reality of the group should be acknowledged in order to advance the goals of managerial behaviour regulation in the context of insolvency, particularly the varied circumstances of control and influence over other entities in the group and the scenarios of misconduct towards financially troubled entities. Indeed, in a group scenario, it could be difficult to identify the precise boundary of a firm, and in some group types, management responsibilities (and thus, liability) may be blurred across the entities' 
boards. Consequently, concepts such as shadow directorship may not fit squarely with the economic realities of groups, and enterprise considerations might be instrumental in shedding light on who should be responsible for mismanagement in the time leading up to insolvency and what are the benefits accruing to creditors from pursuing group interests.

It must be acknowledged, though, that since the international standards (and their extension to groups as proposed here) are premised on a flexible balanced approach, bringing proceedings under the regime would remain somewhat speculative. The standards do not prescribe the specific steps that directors should take at times of trouble, ${ }^{94}$ and they do not point to specific timeframes. Similarly, in a group context an overall assessment of the circumstances will be required in order to ascertain the potential liability of directors and related entities. Still, the explicit treatment of the group case would contribute to greater clarity in this area while retaining the flexibility essential for rescue promotion and the fine balance between limited liability and economic realities. Addressing the matter on the international level would also have the advantage of promoting harmonisation in this area. This is particularly important considering that many groups operate across borders, and since groups could "forum shop" in close proximity to the initiation of insolvency proceedings. ${ }^{95}$ Harmonising the regulation regarding group managerial liabilities could ensure that remedies for group mismanagement are available, wherever the insolvency proceedings against group entities take place.

\footnotetext{
${ }^{94}$ Though the UNCITRAL standards provide more guidance regarding the steps that may be taken by directors, compared with the English wrongful trading provision, which do not delineate any such steps (see WP.113, recommendation 2; cf. English Insolvency Act, s 214).

95 The forum where group members' centres of main interests are located will have jurisdiction to handle the main proceedings under the major cross-border insolvency models. However, COMI is susceptible to a degree of forum selection, not necessarily for the wrong reasons (see e.g. the relocation to the UK of groups such as Hellas Telecommunications and European Directories; Re Hellas Telecommunications (Luxembourg) II SCA [2009] EWHC 3199 (Ch) [2010] B.C.C. 295; Re European Directories (DH6) BV [2010] EWHC 3472 (Ch)).
} 